\title{
APPLE-TREE RESISTANCE TO ABIOTIC FACTORS IN WINTER
}

\author{
Nina Krasova, Anna Galasheva, and Lubov Golishkina \\ All-Russian Research Institute of Fruit Crop Breeding of Russian Academy of Agricultural Sciences, \\ Zhilina, Orel region, 302530, RUSSIA; \\ n.krasova@yandex.ru \\ Communicated by Edite Kaufmane
}

\begin{abstract}
Data on the reaction of apple cultivars to unfavorable autumn-winter conditions were analysed and summarised. New scab resistant apple cultivars (gene $V_{f}$ ) obtained from the hybridisation of local adapted varieties with a donor of scab immunity also displayed hardiness to unfavourable winter conditions. As a result of artificial freezing, the cultivars resistant to spring frost $\left(-3.5^{\circ} \mathrm{C}\right)$ during flowering were identified. The mechanism of adaptation to unfavourable winter conditions, and the possibility of preliminary prediction of winter hardiness according to some indicators of the physiological state of tissues in wintering trees were found. In all apple cultivars, increase of the concentrations of sucrose, anthocyanin and cyanidin was noted during the autumn-winter period, but in winter-hardy cultivars this process was more intensive; the amount of cyanidin in the bark of shoots was 6-8 times higher in comparison with non-winter-hardy cultivars. Higher water loss in non-winter-hardy cultivars was observed under conditions of extreme temperatures, which can lead to significant freezing and sunburns late in winter. In winter-hardy cultivars, peroxidase activity decreased in winter, while in the non-winter-hardy cultivars it remains high, due to incomplete hardening of tissues.
\end{abstract}

Key words: apple, cultivar, winter-hardiness, biochemical methods.

\section{INTRODUCTION}

In Russia, over $70 \%$ of the area is situated in zones that are characterized by extreme cold and extremely dry climate. Irregular factors of the environment significantly reduce the productivity of agricultural crops. Weather instability in winter and during the vegetation period results in a need to determine the mechanisms and structures of adaptive reactions that affect performance of biological components of agrobiocenoses and to study fruit plant adaptation. A basic adaptation index of plants is their productivity, and increase of productivity indicates ecological resistance to unfavourable soil-climatic and environmental conditions. The combination of all necessary adaptation traits needs to be provided in a cultivar at a maximum level (Жученко, 2001). Lately, especially in the middle zone of Russia, apple yields have been distinctly reduced, which has led to economic losses (Гудковский и др., 2005).

Horticulture in a cool temperate climate is a hazardous and power-intensive industry, since its efficiency mostly depends on abiotic factors of the environment (droughts, early frosts, low critical temperatures, thaws, spring frosts and a short vegetation period). Fruit plants are constantly affected by a wide range of stresses. Stresses affect metabolic processes and functional activity and, as a result, yield.

The most important index is considered to be tree winter hardiness, since in severe winters trees of many cultivars are heavily damaged and even perish. A field method of testing is widely used in order to estimate the winter hardiness of different fruit crop cultivars. This method allows variety assessment in different environmental conditions. Winter hardiness assessment may be accelerated by simulation of damaging factors in controlled conditions according to a programme that considers multicomponent character of traits (Forsline, 1983; Coleman and Estabrooks, 1985; Тюрина и др., 1999; Gelvonauskis et al., 2000; Ярмолич и др., 2008).

Potential winter hardiness in fruit plants is associated with their preparation for hibernation and reaction to unfavourable factors of the environment. High winter hardiness of a genotype is formed stage-by-stage: (1) increase after growth termination, (2) transition to the condition of dormancy and (3) low positive temperature hardening. Tree preparation for the hibernation is associated with starch hydrolysis and accumulation of soluble sugars, including sucrose. This has been confirmed by studies on mono- and disaccharide protective functions in relation to protein and lipid complexes (Сергеева, 1971; Починок, 1983; Колупаев and Трунова, 1992; Zhu Liwu et al., 2002; Бирюк, 2004; Ненько и др., 2010).

A complex of quantitative and qualitative indices, which characterize adaptive potential of plants (phenolic compounds, anthocyans, cyanidins, carotenoids etc.), allows to assess resistance of varieties to stress (Еськин, 1960; 
Богомаз и Коршук, 1962; Коэн, 1986; Леонченко и Ханина, 1988; Цуканова, 2001; Wang and Zwang, 2001; Leng et al., 2003; Голышкина и др., 2011; Трутнева, 2011). A role of phenolic compounds in the hardiness of plants has been shown: under lower temperatures phenolic compound concentrations in plant tissues increases (Упадышев, 2008). Significant increase of ascorbic acid content in apple tissues promotes a drop in intensity of free radical processes in cell membranes and improves their resistance (Wang and Faust, 1994; Гудковский и др., 2005; Хаустович и Потапов, 2007; Ненько и др., 2008).

Change in peroxidase and isoperoxidase activity of plants exposed to a cold stress or pathogen has been shown in the reports of many authors (Левитес, 1986; Wu and Zhang, 1990; Карташова и др., 2000; Kozlovskaya and Biryuk, 2003; Трунова, 2007; Guy et al., 2008; Голышкина и др., 2010).

Physiological and biochemical changes in tissues of fruit plants in the period of preparation for winter significantly determine tree winter hardiness. At present, it is possibile to predict different characteristics of a fruit tree according to physiological and biochemical parameters (Дорошенко, 2000; Дорошенко и др., 2005; Ненько и др., 2008; Голышкина и др., 2011). However, the mechanisms of metabolism regulation under extreme conditions has not been studied sufficiently.

Application of physiological and biochemical methods in diagnostics can provide accelerated assessment of genotypes according to their hardiness to winter stresses. The reliability of the assessment and prediction of apple cultivar hardiness to unfavourable winter conditions can be increased by application of a complex of methods combining field observations with laboratory estimation by modelling damage factors and use of physiological and biochemical methods.

Winter-hardy apple cultivars with high stable yields of high-quality fruit are necessary for modern intensive orchards. Early diagnostics of winter hardiness along with field estimation could allow to accelerate the testing and introduction of novel promising varieties.

The aim of this work was to assess apple cultivars for winter hardiness in the field and identify physiological and biochemical parametres of apple resistance to unfavourable factors in the autumn-winter period.

\section{MATERIAL AND METHODS}

The investigation was carried out at the All Russian Research Institute of Fruit Crop Breeding in plots of apple variety testing. Fruit tree winter hardiness was studied in field conditions in 1990-2012 according to common methods of variety testing (Лобанов, 1973). Study of flower hardiness to spring frost, along with field controls, were also carried out in laboratory conditions by simulating freezing in a Temperature/Humidity Cycle Chamber "ESPEC"
PSL-2KPN according to methods of Tyurina (Тюрина и др., 1978) in 2009-2012.

Physiological and biochemical diagnostic methods for accelerated genotype assessment were used for the identification of adaptation mechanisms of apple cultivars in conditions of multiple stresses, as well as to investigate the possibilities of predicting cultivar hardiness to unfavourable winter conditions. Accumulation of reserve substances in vegetative organs during autumn-winter was studied for the identification of quantitative differences and accumulation behaviour in cultivars with different winter hardiness.

One-year-old shoots of standard varieties with different winter hardiness were taken for this study: (1) winter hardy cultivars bred at the Institute: 'Imrus', 'Rozhdestvenskoye', 'Sinap Orlovsky', 'Svezhest', 'Yubilyar' and old cultivar 'Antonovka Obyknovennaya'; (2) non-winter-hardy WestEuropean cultivar 'Priam' for the purpose of comparison. Determination of biochemical composition was carried out in the autumn-winter periods of 2009-2012: carbohydrate (starch, sugars) and phenolic compounds (anthocyan, cyanidin and catechin) concentrations, and activity of the enzymes peroxidase and polyphenoloxidase. The following biochemical methods were used. Starch in shoot tissues was identified by colorimeter method, as described by Pochinok (Починок, 1976). Optic density was measured on a photoelectric colorimeter $(610-660 \mathrm{~nm})$. Starch concentration was determined using a calibration curve, and expressed as $\%$ of raw weight of substance. Phenolic compound (anthocyan and catechin) concentrations were determined by colorimeter method, as described by Ermakov (Ермаков, 1987). Cyanidin content was determined at wavelength $535 \mathrm{~nm}$ by a spectrophotometry method developed by Leonchenko and colleagues (Леонченко и др., 2007) with our modification (Голышкина и др., 2010), including centrifugation with an extractive up to five times (3500$5000 \mathrm{rpm}$, centrifuge Jouan M1812) till full discoloration, when cyanidin transforms into a coloured cation form. Spectral characteristics of the extracted pigment were made on a spectrophotometer "Smart Spec Plus" at $535 \mathrm{~nm}$ (cyanidin-3-galactoside and cyanidin-3-arabinoside).

The isoenzyme composition of peroxidase in cultivars with different levels of winter hardiness was determined in freezing apple leaves (Козловская и др., 2005).

The activity of the isozyme system (peroxidase and polyphenoloxidase, expressed as Em-units of extinction) was measured by a spectrophotometry method (590 and 430 nm), as described by Ermakov (Ермаков, 1987). The analyses were made in two biological and two analytical replications.

Flower and ovary resistance to spring frost and regenerative ability of tissues are also among the most important characteristics of a cultivar (Кеммер и Шульц, 1958; Соловьева, 1967; Лихонос, 1983). 
Significant differences in experimental data were determined by analysis of variance, according to Dospekhov (Доспехов, 1973).

\section{RESULTS}

Long-term study of the winter-hardiness of a large apple variety pool in field conditions allowed to classify the cultivars into groups according to their winter-hardiness. The majority of the studied cultivars of West European and American origin, including scab immune apple cultivars, demonstrated weak tolerance to low winter temperatures in the conditions of the Orel region, and therefore, they cannot be grown in the middle zone of Russia.

High winter-hardiness was observed in old native varieties: 'Arkad Zholty', 'Grushovka Moskovskaya', 'Korichnoye Polosatoye', 'Korobovka', 'Krasnoye Letneye', 'Popovka' and 'Skryzhapel'. The new cultivars developed at our Institute can also successfully tolerate unfavourable conditions of winter.

During the severe winter of 2005/06, resistance at the level of that in 'Antonovka Obyknovennaya' was observed for the following apple cultivars: 'Augusta', 'Orlik', 'Orlovskoye Polosatoye', 'Sinap Orlovsky', 'Veteran', 'Kulikovskoye', 'Pamyat Voinu', 'Orlinka', 'Orlovim', 'Vita', 'Orlovskaya Zarya' and 'Nadiozhnoye'.

New scab resistant apple cultivars (gene $V_{f}$ ) obtained from the hybridisation of local adapted varieties with a donor of scab immunity also displayed resistance to unfavourable winter conditions: 'Imrus', 'Bolotovskoye', 'Svezhest', 'Venyaminovskoye', 'Orlovskoye Polesye', 'Solnyshko', 'Yablochny Spas' and 'Rozhdestvenskoye'. The field experiment data was consistent with the results of simulating artificial freezing in chambers and with investigations of other authors (Сухоцкий, 2005; Савельев и др., 2009; Есичев, 2010).

Repeated light frosts during flowering caused much damage in the orchard. Damage caused by low temperatures largely depended on the extent of blossoming. It was found that a basipetal type of apple inflorescences was associated with protection of flower components in unopened buds. In 1999, for example, the frosts damaged $90-100 \%$ of open flowers in early-blooming cultivars, but pistils of the cultivars with unopened buds remained undamaged.

Artificial freezing of the blossoms and buds with different extent of disclosure, which modelled damage in the spring period, the cultivar reaction to lower temperature during blooming was shown.

According to some reports, the critical temperature for apple trees during blossoming is considered to be from -1.7 to $-5{ }^{\circ} \mathrm{C}$ (Loewel, 1950; Лихонос, 1983). In our conditions, sharp differences in loss of flowers and buds were observed with temperature lower than $-3.5{ }^{\circ} \mathrm{C}$. Taking into account the flower and bud damage with this temperature, the fol- lowing cultivars were considered to be resistant to frost during blossoming: 'Antonovka Obyknovennaya', 'Vita', 'Zhelannoye', 'Zaryanka', 'Kandil Orlovsky', 'Kulikovskoye', 'Kurnakovskoye', 'Papirovka' ('White Transparent') and 'Stroevskoye' (no more than $25 \%$ of the flowers and buds were damaged). The weakest resistance of flowers and buds to low temperature was observed in the triploid cultivars 'Pamyat Semakinu', 'Nizkorosloye', 'Pamyat' Hitrovo' and 'Yubilyar' (Fig. 1).

Cultivar resistance to unfavourable winter conditions was formed gradually, and increased after growth cessation, start of dormancy and low temperature hardening. In apple trees, during hardening by low temperatures in autumn there was an accumulation carbohydrates, proteins and polyphenols, an adaptation for over-wintering. Reactions of genotypes to the environmental conditions during the phases of development and biological processes determining the degree of adaptation, were not identical for cultivars. In autumn, winter-hardy cultivars 'Antonovka Obyknovennaya', 'Imrus', 'Svezhest' and others had high accumulation of starch in
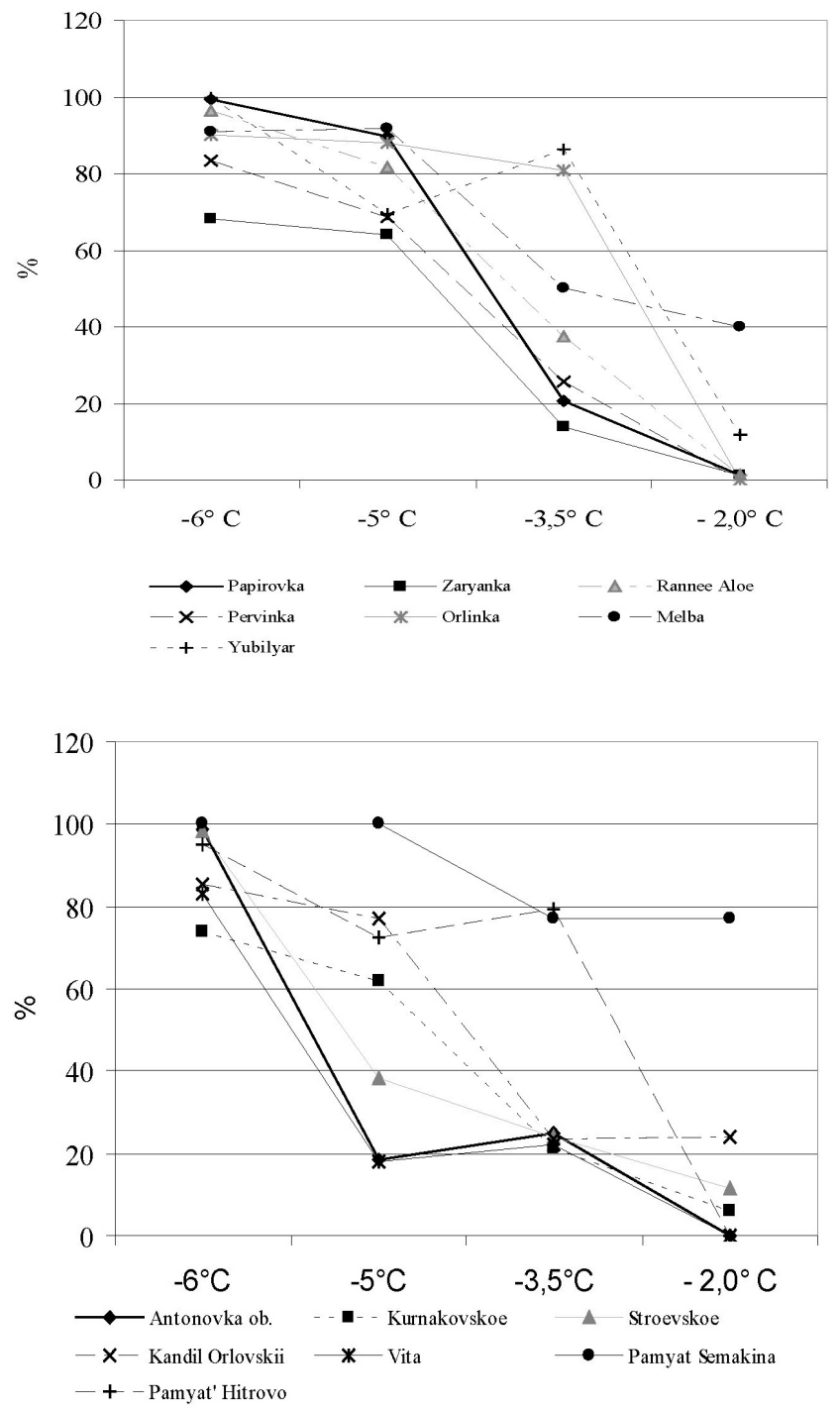

Fig. 1. Damage to flowers and buds of summer (a) and autumn-winter (b) apple cultivars, \%, 2010. 

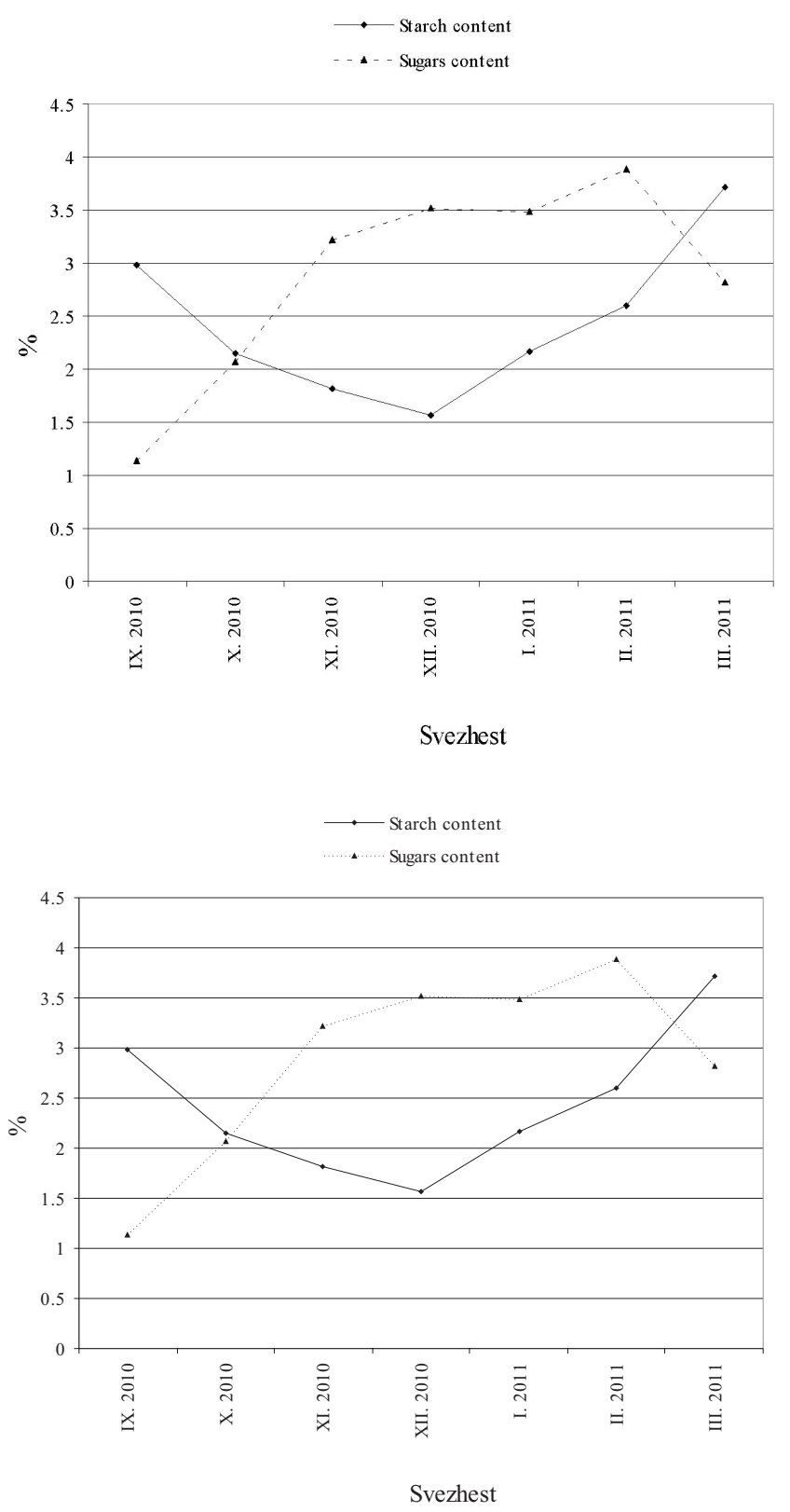

Fig. 2. Dynamics of starch and sugars concentration in shoots of apple cultivars in the autumn-winter period (average for 2009-2012), \%. shoots (up to $3 \%$ on raw weight), followed by intensive hydrolysis. In November and December starch hydrolysis proceeded most actively. During that period sugar concentration in apple shoots increased significantly; in winter-hardy cultivars it remained at a high level for the whole winter (Fig. 2). Late in February, the synthesis of starch was renewed. This process continued until April, and winter-hardy cultivars had higher rates of synthesis.

During the period of hardening the qualitative composition of sugars in apple shoots changed: increase of concentrations of oligosaccharide, including sucrose, which performs a protective role in the winter-hardiness of plants. Also, water content of tissues and peroxidase activity decreased. In winter months, the sucrose concentration in one-year-old apple shoots of winter-hardy cultivars was higher than in the shoots of the non-winter-hardy cultivar 'Priam'. Increased concentration of sucrose was found in one-year-old shoots (especially in the bark) of the following cultivars: 'Antonovka Obyknovennaya', 'Imrus', 'Svezhest', 'Rozhdestvenskoye', 'Sinap Orlovsky' and 'Yubilyar' (Table 1). Those cultivars were had higher intensity of metabolic processes and greater adaptability to local conditions. In shoots of 'Priam' the concentration of sucrose in the autumn-winter period was 1.5-2 times lower than in the shoots of 'Antonovka Obyknovennaya'.

By the end of dormancy, the sucrose content in shoots decreased in all cultivars and at the beginning of the vegetation period, oligosaccharide concentration in the tissues were almost entirely depleted.

Under low temperatures, the activity of physiological processes decreased, and protective mechanisms were activated. At the same time, biosynthesis of phenolic agents (anthocyans, catechins, leucoanthocyans, etc.) took place. The majority of them occur in plants as sugar compounds. Others belong to anthocyans, which provide protection against unfavourable winter conditions. Study of the anthocyan concentration dynamics in different periods showed that in autumn when temperature decreases, the

Table 1

DYNAMICS OF ACCUMULATION OF SUCROSE IN ONE-YEAR-OLD SHOOTS OF APPLE CULTIVARS IN THE AUTUMN-WINTER PERIOD (average for 2009-2012)

\begin{tabular}{|c|c|c|c|c|c|c|c|c|c|}
\hline \multirow[t]{2}{*}{ Cultivars } & \multicolumn{9}{|c|}{ Sucrose content ( $\%$ of raw weight) by month } \\
\hline & IX & $\mathrm{X}$ & XI & XII & I & II & III & IV & average \\
\hline Antonovka Obyknovennaya & 0.28 & 0.62 & 1.17 & 1.05 & 1.23 & 1.25 & 0.86 & 0.69 & 0.89 \\
\hline Imrus & 0.45 & 0.38 & 1.04 & 1.21 & 1.05 & 1.43 & 1.08 & 0.50 & 0.89 \\
\hline Rozhdestvenskoye & 0.16 & 0.82 & 1.10 & 1.27 & 1.16 & 1.21 & 1.15 & 0.97 & 0.98 \\
\hline Svezhest & 0.47 & 0.35 & 1.51 & 1.00 & 1.24 & 1.06 & 1.10 & 0.35 & 0.89 \\
\hline Sinap Orlovsky & 0.65 & 0.53 & 1.11 & 1.55 & 0.90 & 1.70 & 1.13 & 0.81 & 1.05 \\
\hline Yubilyar & 1.23 & 0.77 & 1.05 & 1.32 & 1.98 & 1.77 & 1.72 & 1.79 & 1.45 \\
\hline Priam & 0.52 & - & 0.62 & 0.92 & 0.94 & 0.63 & 0.66 & 0.44 & 0.59 \\
\hline average & 0.54 & 0.58 & 1.08 & 1.19 & 1.24 & 1.29 & 1.10 & 0.79 & 0.28 \\
\hline
\end{tabular}

$\mathrm{LSD}_{05} *$

LSD, Least significant difference 


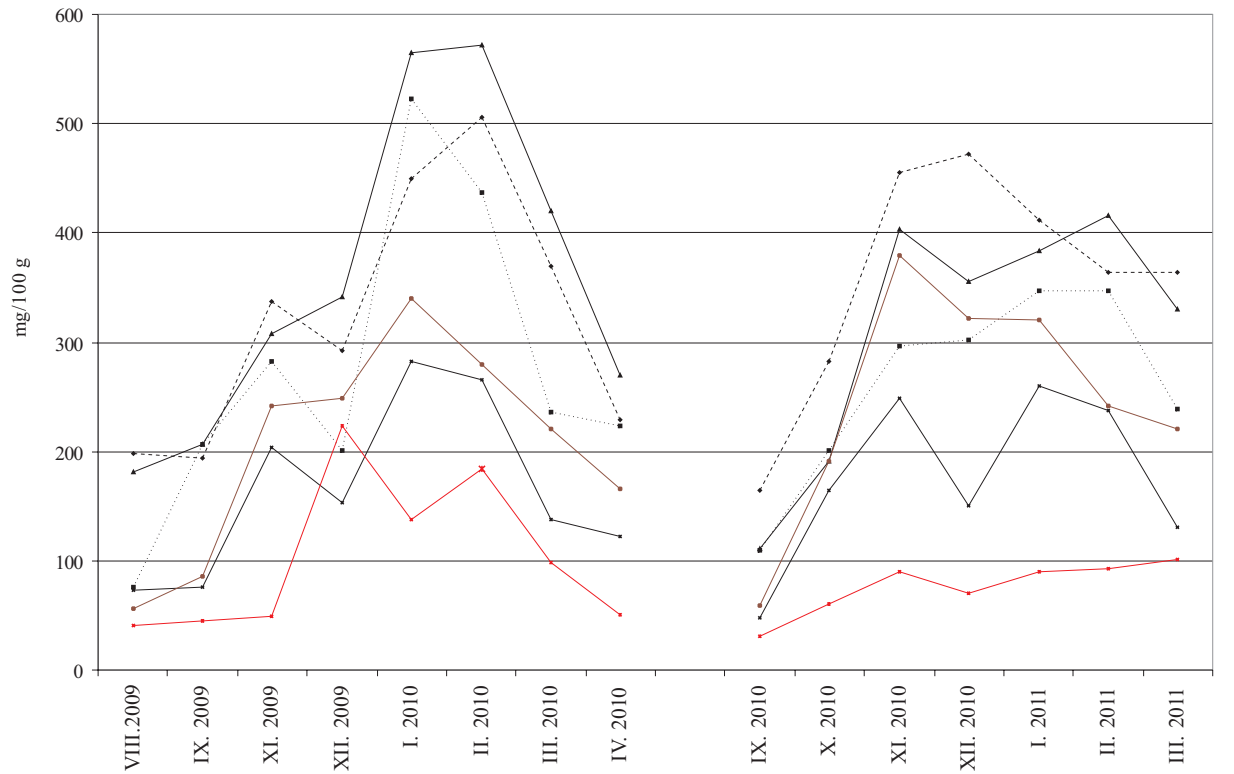

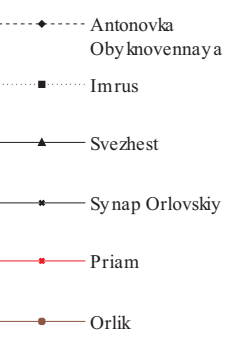

Fig. 3. Dynamics of anthocyan concentration in the bark of shoots of apple cultivars with different winter-hardiness, mg/100 g. anthocyan concentration in one-year-old apple shoots increases rapidly, reaching a maximum in January-February.

Cultivars with different winter-hardiness significantly differed in the concentration of anthocyan in the tissues of one-year-old shoots. In the surface layers of the shoots (in the bark) the concentration of anthocyan was 2-3 times higher than in the cells of the phloem, cambium and cambial zone. The concentration of anthocyan in the bark of winter-hardy cultivars 'Antonovka Obyknovennaya', 'Imrus' and 'Svezhest' was steadily high during the autumn-winter period, 3-4 times exceeding that in the nonwinter-hardy variety 'Priam' (Fig. 3). Maximum anthocyan concentration was observed in the coldest weather.
Cyanidins, which perform a protective function for tolerance to variable temperatures, has the highest concentrations among anthocyans. Cyanidins create a thermo-accumulating and light protecting barrier, giving a reddish and brown tones to the tree bark. A positive relationship was found between cyanidin concentration and winter hardiness of the studied cultivars. Moderate low temperature in autumn of 2010 promoted the synthesis of cyanidin in the bark of the cultivars differently. Cyanidin concentration increased in all cultivars, but in winter hardy ones such as 'Antonovka Obyknovennaya', 'Imrus', 'Orlik' and 'Svezhest' this was more intensive. In winter, the concentration of cyanidin in bark was high (195-337 mg /100g raw

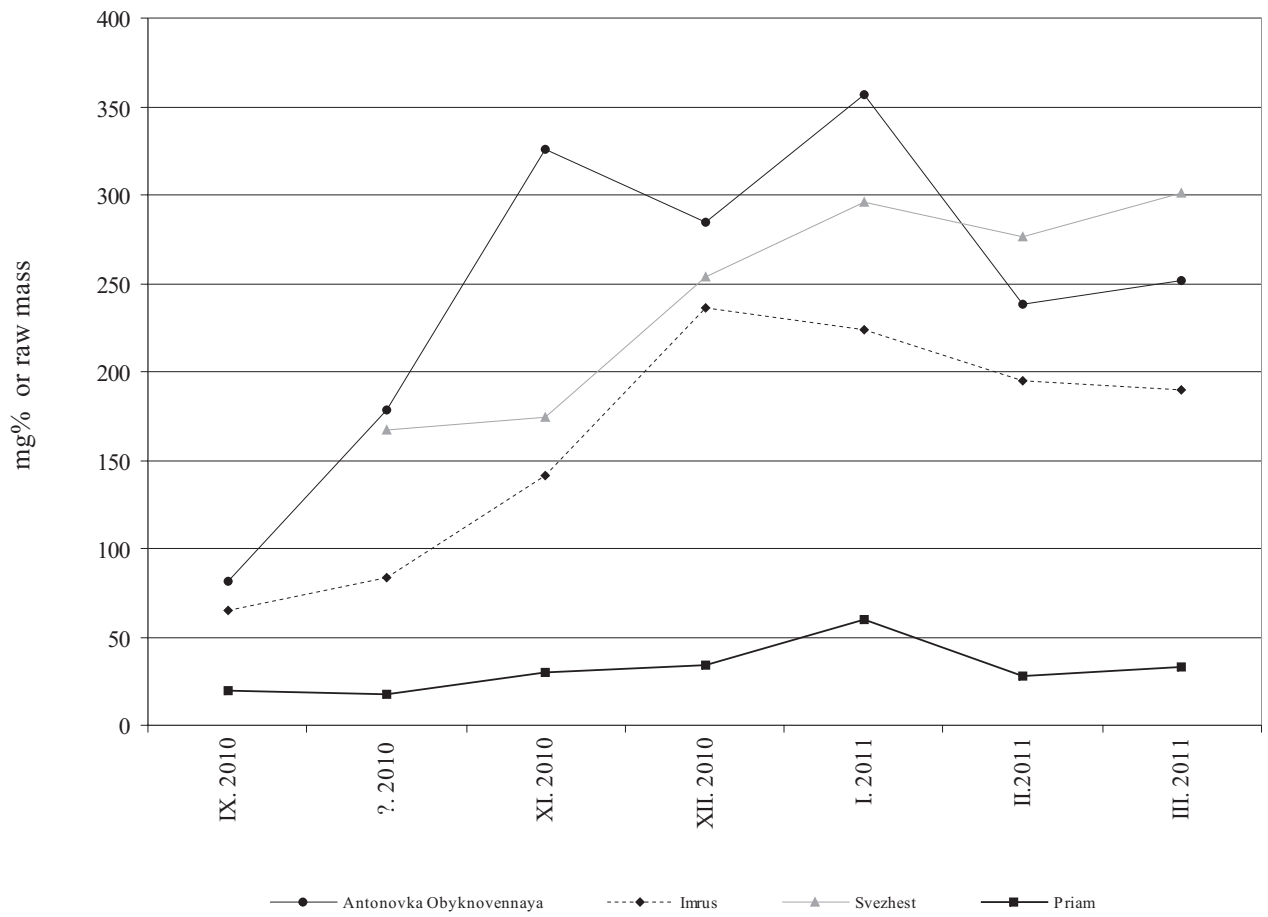

Fig. 4. Cyanidin concentration in the bark of shoots of apple cultivars in the autumn-winter period 2010/2011. 
DYNAMICS OF ACCUMULATION OF CATECHIN IN ONE-YEAR-OLD SHOOTS OF APPLE CULTIVARS IN THE AUTUMN-WINTER PERIOD (average for 2008-2012)

\begin{tabular}{|c|c|c|c|c|c|c|c|c|c|}
\hline \multirow[t]{2}{*}{ Cultivars of apple } & \multicolumn{9}{|c|}{ Catechin concentration (mg/100 g of raw weight) by month } \\
\hline & IX & $\mathrm{X}$ & XI & XII & $\mathrm{I}$ & II & III & IV & average \\
\hline Antonovka Obyknovennaya & 465.7 & 650.3 & 675.3 & 522.9 & 567.2 & 495.3 & 400.9 & 543.1 & 540.1 \\
\hline Priam & 407.7 & - & 553.5 & 488.2 & 490.7 & 548.6 & 424.3 & 494.3 & 504.3 \\
\hline Svezhest & 459.3 & 543.2 & 665.3 & 521.5 & 475.6 & 451.5 & 378.4 & 546.8 & 505.2 \\
\hline Priam & 407.7 & - & 553.5 & 488.2 & 490.7 & 548.6 & 424.3 & 494.3 & 504.3 \\
\hline average & 444.3 & 626.9 & 624.9 & 518.1 & 505.5 & 488.2 & 407.8 & 528.3 & \\
\hline
\end{tabular}

* F-test: Ff - fact, Ft - theoretical

Table 3

PEROXIDASE ACTIVITY IN ONE-YEAR-OLD SHOOTS OF APPLE CULTIVARS IN THE AUTUMN-WINTER PERIOD (average for 2009-2012)

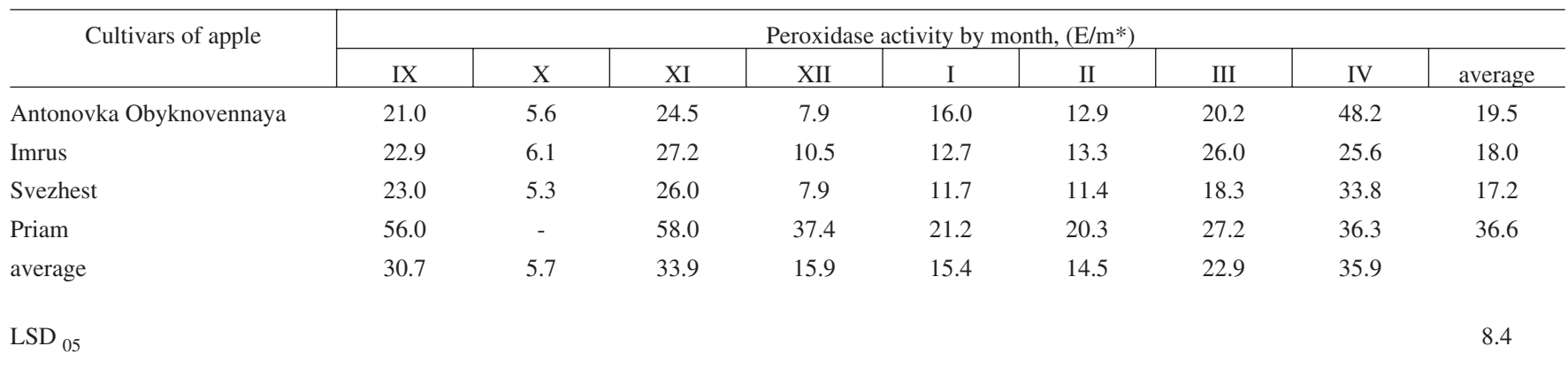

* Em - units of extinction

weight), 6-8 times higher compared to that in the non-winter-hardy 'Priam' (27.5-59.4 mg/100 g) (Fig. 4).

During autumn, decrease of temperature in the periods of hardening and organic dormancy, an increase of the concentration of other phenolic compounds (catechins and leucoanthocyans) was noted in the tissues of apple shoots, but a distinct relationship between the accumulation of those substances and variety winter hardiness was not found (Table 2).

A coordinated and quickly reacting system of oxidative respiratory enzymes is one of the parameters of plant adaptation to winter conditions. It was found that isoenzyme composition of peroxidase differed depending on genotype and the below-zero temperature effect. After a long warm autumn and significant fall of temperature at the beginning of December in 2010, a sharp decline of peroxidase activity was observed in one-year-old shoots of the winter-hardy apple cultivars 'Antonovka Obyknovennaya', 'Imrus' and 'Svezhest'. In the autumn-winter of 2009-2012 the peroxidase activity in one-year-old shoots of these cultivars was 1.7-2 times lower compared to that in the non-winterhardy 'Priam' (Table 3). High peroxidase activity (37.4 Em-units of extinction) in 'Priam' in December was evidence of incomplete tissue hardening and explained the weak winter-hardiness of this cultivar.

Polyphenoloxidase intensified the oxidation of phenols and tanning agents. During shoot growth, the activity of polyphenoloxidase was lower. Its increase in activity in autumn was associated with the oxidative decay of chemical growth factors (auxins, in particular), which impeded growth and plant transition to dormancy. In autumn and winter, polyphenoloxidase activity in hardy apple cultivars was higher (1.3-2.3 Em) than in a non-winter-hardy variety (0.6-1.0 Em) (Table 4). Higher activity of peroxidase and high activity of polyphenoloxidase might be considered as one of the plant adaptability functions contributing to better preparation for the winter period.

\section{DISCUSSION}

Advanced intensive orchards require apple cultivars combining high productivity and fruit quality with high stability to unfavourable conditions of the environment. The development of balanced agro-ecosystems with high and stable productivity is possible only with the use of plant varieties tested for adaptivity. Winter hardiness is one of the parameters that characterises a variety and determines the possibility of its cultivation in a given locality. The field method of variety testing in different environmental conditions is widely used to estimate winter hardiness of fruit crop varieties. The process of variety estimation can be accelerated by damage factor simulation in controlled conditions and indirect methods based on knowledge of the reasons for frost damage and physiological and biochemical features of plant adaptation. Quite numerous reports on physiological and 
POLYPHENOLOXIDASE ACTIVITY IN THE ONE-YEAR-OLD SHOOTS OF APPLE CULTIVARS IN THE AUTUMN-WINTER PERIOD (average for 2009-2012)

\begin{tabular}{l|c|c|c|c|c|c|c|c|c}
\hline \multirow{1}{*}{\multicolumn{1}{c|}{ Cultivars of apple }} & \multicolumn{10}{c}{ Polyphenoloxidase activity by month, (E/m*) } & \multicolumn{1}{c}{ IV } & average \\
\cline { 2 - 10 } & IX & O & XI & XII & I & II & III & I \\
\hline Antonovka Obyknovennaya & 2,2 & 0,9 & 1,5 & 1,5 & 2,3 & 2,1 & 1,3 & 1,3 & 1,6 \\
Imrus & 2,2 & 1,0 & 1,3 & 2,1 & 2,0 & 1,6 & 1,7 & 1,4 & 1,7 \\
Svezhest & 2,1 & 0,9 & 1,3 & 1,5 & 2,0 & 1,3 & 1,3 & 1,1 & 1,4 \\
Priam & 1,2 & 0,6 & 0,5 & 0,7 & 0,6 & 1,0 & 0,6 & 0,7 & 0,7 \\
average & 1,9 & 0,9 & 1,2 & 1,5 & 1,7 & 1,5 & 1,2 & 1,1 & 0,3
\end{tabular}

$\operatorname{LSD}_{05}$

* Em - units of extinction

biochemical methods for identification of winter hardiness of fruit trees have been published. Methods of the carbohydrate identification (Сергеева, 1971; Починок, 1983; Колупаев и Трунова, 1992; Бирюк, 2004), identification of quantitative and qualitative parameters, including enzyme activities, phenolic combinations, and concentrations of anthocyans, cyanidins, carotenoids, ascorbic acid, proteins, prolines, and others (Леонченко и Ханина, 1988; Цуканова, 2001; Wang and Zhang 2001; Kozlovskaya and Biryuk, 2003; Гудковский, 2005; Трунова, 2007; Guy et al., 2008; Упадышев, 2008) are used for assessing winter hardiness. However, used separately, these parameters insufficiently reveal the mechanism of adaptation to unfavourable winter conditions. Our investigations are based on complex estimation of behaviour of varieties in field conditions, by method of artificial freezing and application of physiological and biochemical methods.

It was found that winter hardy apple cultivars have a high degree of starch hydrolysis in the period of hardening. When air temperature sharply falls in December, the sucrose content is increased and remains high during all winter months: on the average, in autumn-winter of 20092012 the concentration of sucrose was $0.89-1.05 \%$ in shoot tissues of cultivars 'Antonovka Obyknovennaya', 'Imrus', 'Orlik', 'Rozhdestvenskoye', 'Svezhest', 'Sinap Orlovsky' and 'Yubilyar', which was significantly higher than in the cultivar 'Priam' $(0.59 \%)$. There was a positive relationship between winter hardiness and concentrations of phenolic compounds: anthocyan concentration in shoots of winter hardy cultivars was 3-4 times higher than that in 'Priam', and the cyanidin concentration was 6-8 times higher. Significant differences were shown for activity of peroxidase and polyphenoloxidase enzymes. In December, peroxidase activity was lower in winter hardy cultivars and remained low till the end of the winter; in the non-winter-hardy cultivar 'Priam' peroxidase activity was significantly higher (on average, $37.4 \mathrm{Em}$ ) during the entire autumn-winter period.

Polyphenoloxidase activity in the non-winter-hardy cultivar remained high during autumn-winter months, indicating weak completion of growth processes and bad hardening of tree tissues.
Significant differences in concentrations of carbohydrates (starch, sugars), anthocyan, and cyanidin and activity of peroxidase and polyphenoloxidase in shoots and bark of apple cultivars were conditioned by genetic specificity of cultivars, which had different types of adaptation. According to the observed seasonal changes for these metabolites it was possible to determine the intensity of physiological and biochemical changes in apple tissues during adaptation to low temperatures.

The complex approach allowed to identify winter hardy apple cultivars and show the mechanism of formation of hardiness during autumn and winter. Physiological and biochemical methods for the diagnostics of the adaptive potential of apple genotypes were developed. Biochemical parameters of apple cultivars in the autumn-winter period (concentrations of starch, sucrose, anthocyans, cyanidins and activities of peroxidase and polyphenoloxidase) can be used to predict apple winter hardiness.

\section{ACKNOWLEDGEMENTS}

This work was financially supported by Russian Foundation for Basic Research (N 12-04-97505) and the Administration of the Orel region.

\section{REFERENCES}

Coleman, W. K., Estabrooks, E. N. (1985). Chemical modification of cold hardiness in apple trees in eastern Canada. Can. J. Plant Sci., 65, 969-975.

Forsline, P. L. (1983). Winter hardiness of common New York apple varieties and rootstocks as determined by artificial freezing. Proc. N.Y. State Hort Soc., 128, 20-41.

Gelvonauskis, B., Duchovskis, P., Bandaraviciene, G. (2000). Investigation of winter hardiness and cold hardiness on apple progenies. Acta Hort., 538, 277-282.

Guy, C., Kaplan, F., Kopka, J. et al. (2008). Metabolomic and plant stress. Physiologia Plantarum, 132, 220-235.

Kozlovskaya, Z. A., Biryuk, E. (2003). Application of peroxidase as a genetic marker to assess the apple adaptation to low temperatures. Vestsi Natsyyanal'naj Akadehmii Navuk Belarusi. Seryya Biyalagichnykh Navuk, 1, 9-13.

Leng, P., Itamura, H., Yamamura, H., Deng, X. M. (2003). Anthocyan accumulation in apple and peach shoots during cold acclimation. Sci. Hort., 83 (1), 43-50. 
Loewel, E. L. (1950). Die Frostschaden in der Blute unserer Obstbaume. Mittlg. d. Obstbauversuchsringes d. Alten Landes, Jork.

Wang S. Y., Faust, M. (1994). Changes in the antioxidant system associated with Budbreak in 'Anna' Apple (Malus domestica Borkh) Buds. J. Amer. Soc. Hort. Sci., 119 (4), 735-741.

Wang, S., Zhang, W. (2001). Effect of plant growth temperature on antioxidant capacity in strawberry. J. Agric. Food Chem., 49 (10), 4977-4982.

Wu, J. R., Zhang, Z. L. (1990). Evaluating the cold resistance of apple trees by means of peroxidase enzyme analysis. J. Fruit Sci., 7 (1), 41-44.

Zhu Liwu, Li Shaowen, Liu Jiafa et al. (2002). Physiological characteristics of resistance of different plum varieties to artificial adverse environments. Chinese J. Appl. Ecol., 4, 395-398.

Артюх С. Н., Ненько Н. И., Красова Н. Г. (2012). Динамика белков и пролина в побегах сортов яблони различной зимостойкости [Dynamics of protein and proline in shoots of apple varieties with different cold-hardiness]. В кн.: Селекция, генетика и сортовая агротехника плодовых культур: сборник научных статей (с. 14-22). Орел. (in Russian).

Бирюк Е. Н. (2004). Динамика сахаров в листьях яблони, подвергнутых холодовому стрессу [Dynamics of sugars in apple leaves been exposed to frost stress]. Плодоводство, 16, 150-154 (in Russian)

Богомаз К. И., Коршук, Т. П. (1962). Антоцианы в коре разных по морозоустойчивости сортов яблони [Anthocyanins in the bark of the varieties of apple with different winter-hardiness]. Вестник Киевского университета, серия Биология, 2 (5), 87-91 (in Russian).

Голышкина Л. В., Красова Н. Г., Галашева А. М. (2010). Активность и полиморфизм некоторых ферментных систем тканей сортов яблони различной зимостойкости [Activity and polymorphism of some enzyme systems of apple varieties with different winter hardiness]. В кн.: Биологические основы садоводства и овощеводства (с. 101-108). Мичуринск (in Russian).

Голышкина Л. В., Галашева А. М, Красова Н. Г. (2011). О характере изменений содержания антоцианов-цианидинов в побегах сортов яблони для диагностики зимостойкости [On the character of changes of anthocyan-cyanidin contents in shoots of apple varieties for winter hardiness diagnostics]. В кн.: Плодоводство и ягодоводство России (с. 129-136). Т. 28, часть 1. Москва (in Russian).

Голышкина Л. В., Галашева А. М., Красова Н. Г., Грюнер Л. А. (2010). К методике определения цианидинов в коре побегов плодовых культур [Approach to the methods of cyanidine determination in the shoot bark of fruit plants]. Совершенствование сортимента и технологий плодово-ягодных культур: материаль международной научнопрактической конференции (с. 59-61). Орел (in Russian).

Гудковский В. А. Каширская Н. Я., Цуканова Е. М. (2005). Стресс плодовых растений [Stress of fruit plants]. Мичуринск 127 с. (in Russian).

Дорошенко Т. Н. (2000). Физиолого-экологические аспекты южного плодоводства [Physiological and Ecological Aspects of the Southern Fruit Growing]. Краснодар. 234 c. (in Russian).

Дорошенко Т. Н., Макарова Э. В., Щербакова Л. Н., Бадь Л. Д. (2005). Оценка устойчивости яблони к критическим температурам зимнего и летнего периода [Evaluation of resistance of apple to the critical temperature of the winter and summer]. В кн.: Селекционно-генетическое совершенствование породно-сортового состава садовых культур на Северном Кавказе (c.107-114). Краснодар (in Russian).

Доспехов Б. А. (1973). Методика полевого опьта [Methods of field experiments]. Москва: Колос. С. 335 (in Russian).

Ермаков А. И. (1987). Методы биохимического исследования растений [Methods of Biochemical Investigation of Plants]. Ленинград: Агропромиздат. 41-43 c. (in Russian).

Есичев С. Т. (2010). Хозяйственно-биологическая оценка сортов селекции ВНИИСПК на Калужском госсортоучастке [Economic-biological evaluation of varieties of VNIISPK breeding at the Kaluga state variety testing center]. Достижения науки и техники АПК, № 04, 21-24 (in Russian).
Еськин Б. И. (1960). Антоциан и морозостойкость растений [Anthocyanin and cold-hardiness of the plants]. Доклады. АН СССР, 130 (5), 1158-1160 (in Russian).

Жученко А. А. (2001). Адаптивная система селекции растений (экологические основы) [Adaptive System of Plant Breeding (Environmental Base)]. Москва: Изд-во Российского университета дружбы народов. Т. 1. 780 c. (in Russian).

Карташова Е. Р., Руденская Г. Н., Юрина Е. В. (2000). Полифункциональность растительных пероксидаз и их практическое использование [Polyfunctionality of plant peroxidases and their practical use]. Сельскохозяйственная биология, № 5, 63-70 (in Russian).

Кеммер Э., Шульц Ф. (1958). Проблема морозоустойчивости плодовых культур [The Problem of Cold-hardiness of Fruit Trees]. Москва: Изд-во иностранной литературы. 135 с. (in Russian).

Козловская 3. А., Камзолова О. И., Бирюк Е. Н. (2005). Методика ускоренной оценки зимостойкости яблони с использованием изоферментного анализа пероксидазы [Methodology of rapid assessment of winter-hardiness of apple trees using isozyme analysis of peroxidase]. Плодоводство, 17 (1), 265-274 (in Belarussian).

Колупаев Ю. Е., Трунова Т. И. (1992). Особенности метаболизма и защитные функции углеводов растений в условиях стрессов [Metabolism features and protective functions of carbohydrates in plants in conditions of a stress]. Физиология и биохимия растений, 24 (6), 523-531 (in Russian).

Коэн Ф. (1986) Регуляция ферментативной активности [Regulation of Enzyme Activity]. Москва: Наука. C. 13-18 (in Russian).

Красова Н. Г., Артюх С. Н., Ненько Н. И. (2012). Оценка зимостойкости сортов яблони по биохимическому составу в условиях Краснодарского края [Winter hardiness assessment of apple varieties according to a biochemical composition in conditions of Krasnodar Territory]. Плодоводство и виноградарство юга России, № 15, 92-100 (in Russian).

Левитес Г. В. (1986). Генетика изоферментных растений [Genetics of Isozyme Plants]. Новосибирск: Наука: 145 с. (in Russian).

Леонченко В. А., Ханина, Н. П. (1988). Динамика иианидинов в коре побегов яблони в период осенней закалки [Cyanidin dynamics in bark of apple shoot during autumn hardening]. Бюллетень научной информации ЦГЛ имени Мичурина, № 45, 28-31 (in Russian).

Леонченко В. Г., Евсеева Р. П., Жбанова Е. В., Черенкова Т. А. (2007). Предварительный отбор перспективных генотипов плодовых растений на экологическую устойчивость и биохимическую иенность плодов (методические рекомендации) [Pre-selection of the Perspective Genotypes of Fruit Plants by the Ecological Stability and Biochemical Value of Fruit (methodical recommendations)]. Мичуринск. 69 с. (in Russian).

Лихонос Ф. Д., (1983). Яблоня [Malus Mill - The Apple-tree]. В кн.: Ф. Д. Лихонос, А. С. Туз, А. Я. Лобачев. Культурная флора СССР (с. 16-125). Москва: Колос (in Russian).

Лобанов, Г. А. (ред.). (1973). Программа и методика сортоизучения плодовых, ягодных и орехоплодных культур [Programme and Methods of Studying Fruit, Berry and Nut Varieties]. Мичуринск. С. 33-45, 318-331 (in Russian).

Ненько Н. И., Красова и др. (2010). Морозостойкость яблони различных сроков созревания в условиях Северо-Кавказского региона [Cold hardiness of apple with different maturing dates in conditions of the North Caucasus region]. Садоводство и виноградарство, № 4, 40-45 (in Russian).

Ненько Н. Н., Сергеев Ю. И., Абреч М. Ю., Схаляко Т. В., Караваева А. В (2008). Физиолого-биохимическая характеристика устойчивости яблони к абиотическим стрессам в различных конструкциях насаждений [Physiological and biochemical characteristics of apple resistance to abiotic stresses in plantations of various designs]. В кн.: Оптимизация технолого-экономических параметров структуры агроценозов и регламентов воздельвания плодовых культур и винограда (c. 111-116). Т. 1. Краснодар (in Russian). 
Починок Х. Н. (1976). Методы биохимического анализа растений [Methods of Biochemical Analysis of Plants]. Киев. С. 134-138. (in Russian).

Починок Х. Н. (1983). Сезонные биохимические изменения в побегах яблони и характеристика морозостойкости сортов [The seasonal biochemical changes in the shoots of apple-tree and characteristics of the winter-hardiness of the varieties]. Физиология и биохимия культурных растений, 15 (5), 499-505 (in Russian).

Савельев Н. И., Савельева Н. Н., Юшков А. Н. (2009). Перспективныле иммунные к парше сорта яблони [Promising Scab Immune Apple Varieties]. Мичуринск. 126 с. (in Russian).

Сергеева К. А. (1971). Физиологические и биохимические основы зимостойкости древесных растений [Physiological and Biochemical Basis of the Winter-hardiness of Wood Plants]. Москва: Наука. 171 c. (in Russian).

Соловьева М. А. (1967). Зимостойкость плодовых культур при разных условиях выращивания [Winter-hardiness of Fruit Trees under Different Conditions of Cultivation]. Москва: Колос. С. 40-48 (in Russian).

Сухоцкий М. И. (2005). Производственное испытание сортов яблони в условиях северо-запада Беларуси [The production testing of apple varieties in the north-west of Belarus]. Белорусское сельское хозяйство, 7 (39), 39-43 (in Belarussian).

Трунова Т. И. (2007). Растения и низкотемпературный стресс [Plants and Cold Stress]. Москва: Наука. 64 с. (in Russian).

Трутнева П. Н. (2011). Содержание антоцианов, хлорогеновой и аскорбиновой кислот в сортах и подвоях сорто-подвойных комбинаций яблони [Contents of anthocyans, chlorogenic and ascorbic acids in apple cultivars and cultivar-rootstock combinations]. Вестник Мичуринского госагроуниверситета, № 1-1, 72-75 (in Russian).

Тюрина М. М., Гоголева Г. А. (1978). Ускоренная оценка зимостойкости плодовых и ягодных растений [Rapid Assessment of Fruit and Berry Plant Winter Hardiness]. Москва. 48 с. (in Russian).

Тюрина М. М., Красова Н. Г., Резвякова С. В., Савельев Н. И., Джигадло Е. Н., Огольцова Т. П. (1999). Изучение зимостойкости сортов плодовых и ягодных растений в полевых и лабораторных условиях [The study of the winter-hardiness of varieties of fruit and berries in the field and laboratory conditions]. В кн.: Программа $и$ методика сортоизучения плодовых, ягодных и орехоплодных культур (с. 74-76) (под ред. Седова Е. Н. и Огольцовой Т. П.). Орел. (in Russian).

Упадышев М. Т. (2008) Роль фенольных соединений в процессах жизнедеятельности садовых растений [Role of Phenolic Compounds in the Process of Vital Functions of Orchard Plants]. ВСТИСП. 330 c. (in Russian).

Хаустович И. П., Потапов В. А. (2007). Зимостойкость и стресс у яблони [Winter hardiness and stress in apple]. Агро, 21 (10-12), 43-44 (in Russian).

Цуканова Е. М. (2001). Реакция отдельных биохимических показателей растений на воздействие дестабилизирующих факторов [The response of some biochemical indices of plants on the influence of destabilizing factors]. Основные итоги и перспективы научных исследований ВНИИС им. Мичурина (1931-2001), 2, 23-36 (in Russian).

Ярмолич С. А., Козловская 3. А., Бирюк Е. Н. (2008). Использование прямого и косвенного методов оценки исходных форм яблони на зимостойкость [Usage of direct and indirect methods of assessment of initial forms of apple on winter-hardiness]. Плодоводство, 20, 25-33 (in Belarus)

Received 20 December 2012

\section{ĀBEL̨U IZTURĪBA PRET ABIOTISKIEM FAKTORIEM ZIEMĀ}

Rakstā analizēti un apkopoti dati par ābeḷu škirṇu reakciju uz nelabvēlīgiem rudens-ziemas apstākḷiem. Jaunās kraupja rezistentās ābeḷu škirnes (gēns $V_{f}$ ), kas iegūtas, krustojot vietējās adaptētās šķirnes ar kraupja imunitātes donoru, uzrādīja izturību nelabvēlīgos ziemas apstākḷos. Mākslīgās saldēšanas rezultātā identificētas škirnes, kas izturīgas pret pavasara salnām $\left(-3.5^{\circ} \mathrm{C}\right)$ ziedēšanās laikā. Izpētīts adaptācijas mehānisms nelabvēlīgos ziemas apstākḷos un iespēja prognozēt ziemcietību pēc dažiem ziemojošā koka audu fizioloğiskā stāvokḷa indikatoriem. Visām ābeḷu šķirnēm rudens-ziemas periodā atzīmēts saharozes, antocianīnu un cianidīna satura pieaugums, taču ziemcietīgajām škirnēm šis process bija intensīvāks, un cianidīna daudzums dzinumu mizā bija 6-8 reizes augstāks nekā neziemcietīgām šḳirnēm. Ekstrēmu temperatūru ietekmē neziemcietīgajām šķirnēm novērots liels ūdens zudums; tas varētu izraisīt būtisku apsalšanu un saules apdegumus ziemas beigās. Ziemcietīgām šķirnēm ziemā peroksidāzes aktivitāte pazeminās, savukārt neziemcietīgām tā saglabājas augstu nepilnīgu audu norūdīšanās procesu dēl. 